\title{
ANALISIS KETERCAPAIAN INDIKATOR STANDAR PROSES DI SEKOLAH MENENGAH PERTAMA
}

\author{
${ }^{1)}$ Dwitri Stepanili, ${ }^{2)}$ Chaerul Rochman, dan ${ }^{3)}$ Bambang Samsul \\ ${ }^{1}$ UIN Sunan Gunung Djati Bandung, Jawa Barat, Indonesia \\ E-mail: 'dstepanili@gmail.com
}

\begin{abstract}
This article aims to determine the achievement of the standard education process at Cisaat 1 Public Middle School. This research is a descriptive qualitative research by collecting data in the form of observation, interviews and documentation. The results of this study indicate that the attainment of process standards at Cisaat 1 Public High School is $96.2 \%$ when compared to all the maximum scores that should be achieved in the standard process forms. This study recommends exploring the indicators that have not been optimally achieved, especially indicators of a maximum of 32 people. Although it feels good, empowerment, utilization and maintenance of the learning process in schools must be improved. This is intended to improve the quality of education and satisfaction of community expectations.

Keywords: Profile of indicators achievement, implementation of process standards, education
\end{abstract}

\begin{abstract}
Abstrak. Artikel ini bertujuan untuk mengetahui ketercapaian standar proses pendidikan di SMPN 1 Cisaat. Penelitian ini merupakan penelitaian kualitatif deskriptif dengan pengumpulan data berupa observasi, wawancara dan dokumentasi. Adapun hasil penelitian ini menunjukkan bahwa pencapaian standar proses di SMPN 1 Cisaat sebesar 96,2\% jika dibanding dengan seluruh skor maksimum yang seharusnya dicapai pada borang standar proses. Penelitian ini merekomendasikan untuk mendalami indikator-indikator yang belum tercapai dengan optimal khususnya indikator rombongan belajar maksimum 32 orang. Meski dirasa telah baik, namun pemberdayaan, pemanfaatan dan pemeliharaan proses pembelajaran disekolah harus ditingkatkan. Hal ini dimaksudkan untuk meningkatkan mutu pendidikan dan pemuasan harapan masyarakat.

Kata Kunci: Profil ketercapaian indikator, pelaksanaan Standar proses, pendidikan
\end{abstract}

\section{Pendahuluan}

Pendidikan

Indonesia dihadapkan pada berbagai tantangan, baik tantangan internal maupun tantangan eksternal. Tantangan internal adalah banyak sekolah yang belum memenuhi delapan Standar Nasional Pendidikan (SNP). Sementara tantangan eksternalnya adalah globalisasi yang telah merambah ke semua aspek kehidupan masyarakat, dan diberlakukannya Masyarakat Ekonomi ASEAN sejak tahun 2015, sehingga berimplikasi pada semakin terbukanya persaingan antar negara-negara ASEAN. Saat ini data kualitas pendidikan Indonesia berada di urutan ke 109 dunia dari 174 negara, sementara pada level Asia, Indonesia berada pada urutan ke17 dari 17 negara di bawah Vietnam (survei Political and Economic Risk Consultant (PERC)). Pada survei lain yang dilakukan oleh OECD (Organisation for Economic Co operation and Development) pada tahun 2015, Indonesia menempati peringkat ke-69 dari 76 negara. 
Pemerintah Indonesia sesungguhnya telah menetapkan standar yang harus dicapai oleh sekolah untuk menjaminkan pelaksanaan di lapangan, yang meliputi Standar kompetensi lulusan (SKL), standar isi, standar proses, standar pendidik dan tenaga kependidikan, standar pengelolaan, standar sarana dan prasarana, standar pembiayaan, dan standar penilaian. Pada tingkat pelaksanaannya sekolah harus merencanakan dan melaksanakan standar-standar tersebut agar mutu pendidikan dapat ditingkatkan.

Penerapan standar sebagai kondisi yang dinamis. Idealnya target yang ditetapkan makin lama, makin tinggi. Dalam beberapa waktu belakangan ini masalah yang sedang sekolah hadapi makin jelas. Ternyata, menerapkan standar nasional pendidikan di Indonesia bukan perkara mudah. Sebagian sekolah, pendidik dan tenaga kependidikan memiliki keterbatasan pemahaman dan keterampilan menerapkan standar. Dengan bergulirnya kebijakan untuk menerapkan standar mutu sumber daya pendidikan tidak berkembang dengan sendirinya.

Salah satu bukti nyata direncanakan dan dilaksanakannya standar-standar tersebut dapat dilihat dari pelaksanaan proses pembelajaran. Kegiatan ini merupakan inti dari pelaksanaan pendidikan di sekolah. Oleh karena itu, kegiatan pembelajaran harus dikelola dengan baik oleh pelaku pendidikan terutama guru. Pengelolaan dalam kegiatan pembelajaran disebut dengan manajemen pembelajaran.

Standar proses pembelajaran merupakan salah satu standar yang selalu dilakukan perbaikan dan peningkatan secara berkelanjutan karena perannya yang sangat strategis dalam menjamin mutu pendidikan. Dalam hal ini, SMPN 1 Cisaat tidak hanya sekedar menyelenggarakan pembelajaran saja, namun juga menjamin bahwa proses pembelajaran harus berkualitas. Kualitas proses pembelajaran dinyatakan dalam bentuk pemenuhan dan pencapaian standar-standar dalam pembelajaran. Standar-standar tersebut akan menjadi pedoman seluruh aktivitas proses pembelajaran, mulai dari perencanaan, pelaksanaan dan monitoring /evaluasi. Pengembangan mutu pembelajaran melalui serangkaian kegiatan yang tersistem tersebut dilakukan untuk menjamin ketercapaian tujuan-tujuan kurikulum yang telah ditetapkan.

Dari pengertian tersebut ada beberapa hal yang perlu di garis bawahi. Pertama, SNP yang berarti standar ini berlaku untuk setiap lembaga pendidikan formal pada jenjang pendidikan tertentu dimanapun pendidikan itu berada secara nasional. Kedua, standar proses pendidikan berkaitan dengan pelaksanaan pembelajaran, yang berarti dalam standar proses pendidikan berisi tentang bagaimana seharusnya proses pembelajaran berlangsung. Ketiga, standar proses diarahkan untuk mencapai standar kompetensi lulusan.

Standar Proses untuk Satuan Pendidikan Dasar dan Menengah merupakan salah satu acuan utama bagi satuan pendidikan dalam keseluruhan proses penyelenggaraan pembelajaran, mulai dari perencanaan proses pembelajaran, pelaksanaan proses pembelajaran, penilaian hasil pembelajaran dan pengawasan proses pembelajaran. Pemberlakuan standar proses pada satuan pendidikan diharapkan dapat meningkatkan mutu lulusan dalam mencapai standar kompetensi lulusan yang pada akhirnya mampu meningkatkan mutu pendidikan.

Standar proses merupakan variabel yang perlu diperhatikan untuk dapat menghasilkan output yang memiliki kualitas kompetitif. Maka dari itu sangat diperlukan terjadinya suatu proses pendidikan atau pembelajaran yang optimal. Untuk menjadikan proses 
pembelajaran tersebut optimal, diperlukan berbagai usaha untuk perbaikan dan peningkatan, termasuk dengan melakukan penjaminan mutu proses pembelajaran.

\section{Metode Penelitian}

Metode yang digunakan dalam penelitian ini adalah deskriptif kualitatif, populasi pada penelitian ini adalah SMPN 1 Cisaat di Kabupaten Sukabumi. Teknik pengumpulan data menggunakan observasi, dokumentasi dan wawancara.

Dalam penelitian ini digunakan 3 teknik pengumpulan data, yaitu: 1) Observasi, melakukan penelitian lapangan. 2) wawancara, yakni metode pengumpulan jawaban atau informasi yang dilakukan dengan memberi pertanyaan langsung responden berkaitan dengan 21 indikator standar proses kepada pendidik dan tenaga kependidikan di sekolah. 3) Dokumentasi, dokumentasi digunakan untuk mencari data melalui beberapa arsip dan dokumentasi, surat kabar, majalah, jurnal, buku, dan benda-benda lainnya yang relevan.

Jenis data dalam penelitian ini adalah data primer dan data sekunder. Data primer adalah data yang diperoleh langsung oleh peneliti, yaitu data standar proses yang diperoleh melalui observasi menggunakan lembar Instrumen standar proses. Data sekunder adalah data yang diperoleh peneliti dari sumber yang sudah ada, yaitu dokumentasi, data inventaris sekolah dan wawancara dengan pihak sekolah. Data dikumpulkan dengan teknik observasi dan analisis dokumen.

Analisis data hasil observasi dilakukan dengan cara mengkompilasi dan menginterpretasikan secara kualitatif. Analisis data hasil wawancara diberi skor sehingga diperoleh skor total yang menunjukkan tingkat ketercapaian indikator-indikator pada standar proses. pendidikan atau pembelajaran yang optimal. Untuk menjadikan proses dalam proses pembelajaran yang layak.

a. Bobot 3 adalah bobot yang mendukung fungsi butir tersebut dalam proses pembelajaran yang cukup.

b. Bobot 4 adalah bobot yang mendukung fungsi butir tersebut dalam proses pembelajaran yang baik.

c. Bobot 5 adalah bobot maksimal yang mendukung fungsi butir tersebut dalam proses pembelajaran yang sangat baik.

Seluruh butir pernyataan Instrumen merupakan pernyataan tertutup masing-masing dengan lima opsi jawaban yaitu A, B, C, D, dan E. Ketentukan skor setiap opsi jawaban sebagai berikut.

a. Butir pernyataan yang dijawab A memperoleh skor $=5$

b. Butir pernyataan yang dijawab B memperoleh skor $=4$

c. Butir pernyataan yang dijawab $\mathrm{C}$ memperoleh skor $=3$

d. Butir pernyataan yang dijawab D memperoleh skor $=2$

e. Butir pernyataan yang dijawab $\mathrm{E}$ memperoleh skor $=1$

\section{Hasil Dan Pembahasan}

Berdasakan hasil pengambilan dan analisis data tentang ketercapaian indikator pada Standar Proses pada SMPN 1 Cisaat maka dapat disajikan profil ketercapaian indikator Standar Proses, Distribusi Indikator, komposisi kualifikasi standar proses dan masalah serta tindak lanjut perbaikan capaian indikator Standar Proses sebagai berikut. 


\section{Profil Ketercapaian Indikator Standar Proses}

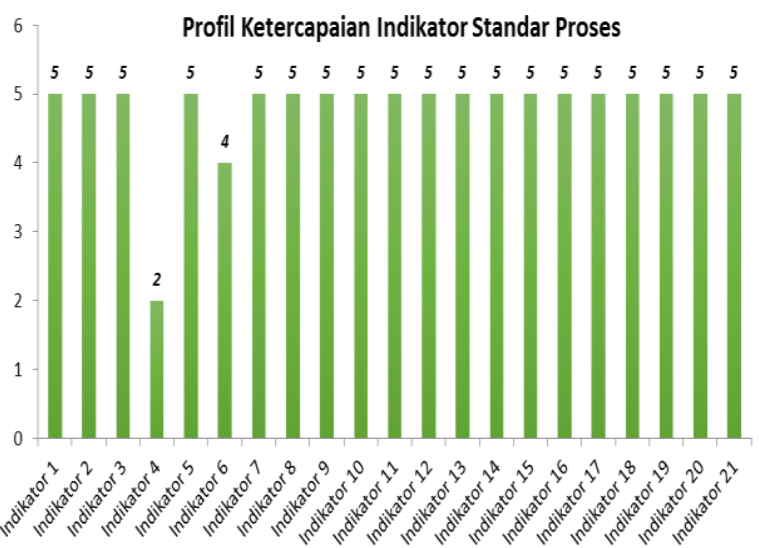

Gambar 1. Profil Ketercapaian Indikator

Standar Proses
Profil ketercapaian indikator

Standar Proses pada SMPN 1 Cisaat dapat ditunjukkan dengan grafik pada gambar 1 berikut.

Gambar 1 menunjukkan profil ketercapaian indikator Standar Proses pada SMPN 1 Cisaat. Dari 21 indikator, ada 2 indikator yang perolehan skor kurang dari 5, yaitu indikator 4 dan 6 . Indikator 4 dan 6 pada Standar Proses ini menyangkut aspek jumlah siswa maksimal dalam satu rombongan belajar (32 orang). Sedangkan indikator 6 menyangkut pengelolaan kelas yang hanya melibatkan 10-11 kriteria guru dalam melakukan pengelolaan kelas yang baik (keadaan ideal sebanyak 12 kriteria). Jumlah skor total yang dicapai pada standar proses di atas adalah 101 dari skor maksimal 105. Sehingga secara keseluruhan capaian standar proses adalah $96,2 \%$.

Berdasarkan analisis data di atas, diketahui bahwa indikator yang belum mencapai skor optimal adalah jumlah peserta didik dalam satu kelas (rombongan belajar). Seperti halnya disimpulkan oleh Sule (2016) bahwa jumlah siswa dalam satu rombongan belajar berpengaruh kepada keberhasilan belajar mereka. Demikian pula menurut Adeyela (2000) bahwa Jumlah peserta didik yang besar dalam satu kelas akan berpengaruh kepada hasil pembelajaran. Senada dengan kedua hasil penelitian di atas, Time (2003) mengkaji bahwa jumlah siswa dalam satu kelas akan berpengaruh kepada kualitas layanan pembelajaran.

Indikator yang belum optimal dicapai oleh sekolah SMPN 1 Cisaat adalah indikato kenam yaitu menyangkut kualitas pengelolaan kelas oleh guru. Seperti halnya disimpulkan oleh Dicke et al (2015) bahwa kemampuan dalam pengelolaan kelas akan berpengaruh kepada kemampuan pedagogic tenaga pendidikan pemula. Demikilan pula menurut Wolff (2017) menyimpulan bahwa kemampuan guru dalam pengelolaan kelas mempengaruhi perlaku dan disiplin peserta didik. Berkaitan dengan upaya meningkatkan kemampuan pengelolaan kelas, Piwowar et al (2013) memberikan solusi bahwa untuk meningkatkan kemampuan pengelolaan kelas diperlukan pelatihan khusus.

Berdasarkan hasil analisis data dan beberapa hasil penelitian tentang jumlah peserta didik dalam kelas dan pengelolaan kelas, maka dapat dilakukan upaya-upaya yang berkaitan dengan kebijakan maupun teknik pedagogic. Jumlah peserta didik dalam satu kelas (rombongan belajar) hendaknya dibatasi, yaitu maksinal 32. Jumlah peserta didik dalam satu kelas sangat berpengaruh terhadap kualitas pelayanan 
pembelajaran dan hasil belajar. Demikian pula untuk meningktakan kemampuan pengelolaan kelas, setiap tenaga pendidik harus mendapatkan pelatihan khusus.

Profil ketercapaian 21 (duapuluh satu) indikator standar proses dapat ditunjukkan melakui hasil wawancara bersama Wakasek Kurikulum di SMPN 1 Cisaat memberikan keterangan terkait ketercapain indikator yakni SMPN 1 Cisaat selalu memuat 9 komponen dalam silabus lalu $100 \%$ beliau mengaskan bahwa mata pelajaran memakai RPP dan Silabus secara lengkap dan sistematis, sesuai dengan 4 ketentuan dalam mengalokasikan waktu dan beban belajar.Mengenai buku teks pelajaran, proses pembelajaran 100\% menggunakan buku teks.

Untuk pembelajaran di SMPN 1 Cisaat selalu memakai langkah-langkah dengan 5 langkah pendahuluan, Model pembelajaran yang sesuai dengan karakter siswa itu 91-100 guru menggunakan model yang sesuai. Guru menggunakan metode pembelajaran sesuai dengan karakteristik siswa 91100. Media pembelajarannya pun $91-100$ Guru menggunakan media yang sesuai. Sumber belajar yang sesuai dengan karakteristik sisiwa dan mata pelajaran mencapai 91-100.

Dalam pendekatan pembelajaran sesuai dengan karakteristik siswa, lalu guru bersama siswa dalam mengakhiri pembelajaran itu melalukan 4 langkahlangkah penutup. Guru juga menggunakan pendekatan penialaian autentik dalam penilaian proses pembelajaran. Guru juga memanfaatkan penilaian autentik dalam merencanakan program remidial, pengayaan, pelayanan, konseling, perbaikan proses pembelajaran.

Berdasarkan perbandingan dan

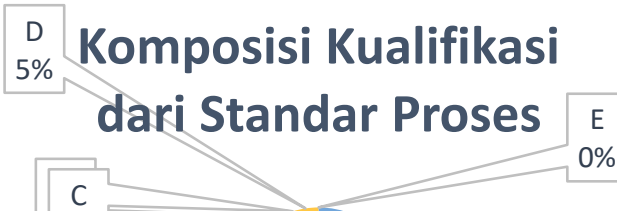

Gambar 2. Komposisi Kualifikasi dari Standar Proses

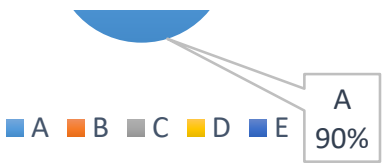

analisis hasil penelitian yang telah dilakukan pada SMPN 1 Cisaat dan penelitian sejenis maka diperoleh informasi tentang kelemahan yang dialami oleh beberapa SMP, yaitu guru merasa kesulitan dalam merancang pembelajaran aktif bagi peserta didik, guru merasa kesulitan dalam menentukan metode yang tepat sesuai dengan karakteristik peserta didik, guru merasa kurang mampu menginovasikan media pembelajaran.

Untuk membantu ketercapaian peroleh Standar Proses keikutsertaan guru-guru dalam wadah MGMP, dan kemampuan guru menerjemahkan satuan kurikulum ke dalam proses pembelajaran kepada peserta didik secara aplikatif. maka dapat diketahui bahwa penerapan standar proses yang sesuai dengan mekanisme peraturan perundangan-undangan dalam sistem pendidikan nasional adalah tercapainya proses pembelajaran yang efektif, efisien dan berkualitas.

\section{Komposisi Kualifikasi Standar Proses}

Adapun komposisi kualifikasi standar sarana dan prasarana dapat ditunjukkan dengan diagram grafik berikut : 
Berdasarkan deskripsi data pada Gambar 2, maka pembahasannya bahwa, SMPN 1 Cisaat melaksanakan proses pembelajaran dengan jumlah siswa rombongan itu tidak mencapai kualifikasi 32 orang tetapi maksimalnya 38 orang alasannya karena membuldaknya peminat masuk ke SMPN 1 Cisaat sehingga adanya kebijakan-kebijakan dari Dinas untuk memberikan siswa tambahan sampai maksimal 38 orang siswa.

Indikator yang belum optimal dicapai dalam penelitian ini adalah indikator keenam yaitu menyangkut kualifikasi rombongan belajar halnya disimpulkan oleh Barliana (2017) Kebijakan untuk meningkatkan rasio jumlah siswa perlu didukung oleh kebijakan untuk meningkatkan kualitas dan kuantitas guru, infrastruktur, diversifikasi keterampilan dan penyerapan lulusan di pasar kerja. Demikian pula Fahmi (2017) Pengamatan perilaku untuk memperoleh data karakteristik siswa yang menjadi acuan dalam penyusunan konsep desain interior ruang pembelajaran.

Dalam pengelolaan kelas yang baik yang melakukan 10-11 kriteria karena ada salah satu guru yang belum bisa bersosialisasi dan belum menjadi suatu kebiasaan. Indikator yang belum optimal dicapai dalam penelitian ini adalah indikator kesebelas yaitu menyangkut kualifikasi rombongan belajar halnya disimpulkan oleh Reski (2016), bahwa prestasi kerja guru yang baik akan membawa pengaruh pada proses belajar mengajar di sekolah dan prestasi peserta didik di sekolah. Tidak optimalnya prestasi kerja guru disebabkan oleh beberapa faktor yaitu
Kualifikasi pendidikan.pengalaman kerja dan disiplin kerja. Demikian pula Oyama (2015) kriteria guru penentu yang memiliki faktor paling besar dan kemudian di buat suatu sistem pendukung keputusan untuk menentukan penerima beasiswa dengan metode Analytical Hierarchy Process.

Proses pembelajaran, mulai dari perencanaan, pelaksanaan, penilaian, pengawasan, kegiatan tindak lanjut serta faktor pendukung dan penghambat pembelajaran merupakan aspek terpenting dalam penyelenggaraan pendidikan di sekolah. Itulah sebabnya mutu pendidikan di sekolah dapat diukur dari aspek ini. Pertama, menyangkut efektivitas perencanaan pembelajaran menyangkut silabus maupun RPP pada SMPN tersebut, bahwasanya perencanaan merupakan salah satu tahapan penting dalam sistem pembelajaran.

\section{Alternatif Solusi Untuk Menjawab Tantangan}

Berdasarkan hasil penelitian yang telah dikemukakan diatas diketahui bahwa keterlaksanan standar proses ikut dipengaruhi oleh perencanaan program pengajaran yang memadai dan utuh. Keutuhan program pengajaran tampak jelas dari tersedianya Intrumen perangkat pembelajaran guru. Perangkat pembelajaran dalam hal ini merupakan pedoman teknis untuk pencapaian tujuan program pengajaran kepada peserta didik di kelas. Oleh karena itu, penyusunan program pengajaran mutlak dilakukan guru pada saat akan melaksanakan tugas pokok dan fungsi utamanya. 
Berpijak pada temuan penelitian sebagaimana telah dikemukakan, dapat diketahui bahwa penerapan standar proses yang sesuai dengan mekanisme peraturan perundangan-undangan dalam sistem pendidikan nasional adalah tercapainya proses pembelajaran yang efektif, efisien dan berkualitas. Efektif dalam arti mampu memanfaatkan potensi sumber daya manusia dan sarana prasarana yang tersedia di sekolah secara tepat guna, efisien dalam makna mampu meminimalisir kelemahan yang dimiliki menjadi kekuatan pendorong dalam optimalisasi proses pembelajaran, serta berkualitas dalam arti memampukan peserta didik memperoleh prestasi belajar yang baik.

\section{Kesimpulan}

Berdasarkan temuan tersebut, maka disarankan bagi kepala sekolah sebaiknya menyelenggarakan pengawasan dan evaluasi pembelajaran secara rutin, dengan perencanaan dan pemetaan terlebih dahulu, sehingga dapat meningkatkan peran guru melaksanakan proses pembelajaran. Kepala sekolah perlu menyelenggarakan pelatihan dan diskusi rutin untuk perbaikan pembelajaran agar guru dapat menyelesaikan permasalahan ketika proses pembelajaran berlangsung. Bagi guru diharapkan secara rutin dapat mengevaluasi perencanaan pembelajaran yang disesuaikan dengan kondisi peserta didik dan karakterisktik materi pelajaran.

\section{Daftar Pustaka}

Dicke, Theresa, Jill Elling, Annett Schmeck, and Detlev Leutner. "Reducing reality shock: The effects of classroom management skills training on beginning teachers." Teaching and Teacher Education 48 (2015): 1-12.

Fahmi, Erwin Feisal, Jenny Ernawati, and Rinawati P. Handajani. "Kriteria Interior Ruang Pembelajaran Siswa SDLB-C Yang sesuai dengan Karakteristik Siswa Tunagrahita Ringan (Studi Kasus SDLB Pembina Tingkat Nasional Bagian C Malang)." Jurnal Mahasiswa Jurusan Arsitektur 5, no. 4 (2017).

Oyama, Sunggito, Ernawati Ernawati, and Paulus Mudjihartono. "Analisis Kriteria Sistem Pendukung Keputusan Beasiswa Belajar Bagi Guru Menggunakan Metode Analytic Hierarchy Process (AHP)." Jurnal Dinamika Informatika 5, no. 1 (2015).

Sule, Samuel Sardauna. "Effects Of Assignment And Class Size On Secondary School Students' achievement In Mathematics." ATBU Journal of Science, Technology and Education 4, no. 2 (2016): 9-16.

Time, Prime. "Star,(2003). State wide class size studies." Review of Educational Research 73: 321-368.

Wolff, Charlotte E., Halszka Jarodzka, and Henny PA Boshuizen. "See and tell: Differences between expert and novice teachers' interpretations of problematic classroom management events." Teaching and Teacher Education 66 (2017): 295-308. 